\title{
HMGA2/LHFP Fusion Gene
}

National Cancer Institute

\section{Source}

National Cancer Institute. HMGA2/LHFP Fusion Gene. NCI Thesaurus. Code C99423.

A fusion gene that results from a chromosomal translocation $t(12 ; 13)(q 13-15 ; q 12)$ which

fuses exons 1-3 of the HMGA2 gene to the 3 ' portion of the LHFP gene. This

rearrangement is associated with lipoma. 